\title{
PROFESIONALISME GURU PENDIDIKAN AGAMA ISLAM DI MADRASAH
}

\section{Oleh: Kamaruddin ${ }^{32}$}

\begin{abstract}
Abstrak
Pendidikan adalah tonggak perkembangan sebuah bangsa, melalui pendidikan yang berkualitas tentu berkorelasi dengan daya saing sebuah bangsa. Salah satu elemen penting dalam pendidikan adalah ketersediaan tenaga guru. Sebagai bagian dari elemen penting dalam dunia pendidikan, profesionalitas peran guru dalam proses pembelajaran, pengajaran dan pendidikan memiliki pertalian dengan peningkatan mutu pendidikan. Menanggapi kondisi tersebut, telah ditempuh berbagai upaya pembenahan sistem pendidikan dan perangkatnya di Indonesia terus dilakukan. Sesuai dengan penjelasan permendikbud No 16 Tahun 2007, tentang kompetensi profesional guru, maka seorang guru agama Islam baik yang mengajar di madrasah maupun lainya wajib memiliki wawasan keilmuan yang terkait dengan mata pelajaran pendidikan agama Islam yaitu mata pelajaran alQuran-Hadits, fikih, akidah-akhlak, dan sejarah Islam.
\end{abstract}

\section{Kata Kunci: Profesionalisme, Guru PAI, Guru Madrasah.}

\section{Pengertian Profesional Guru Agama Islam.}

Profesionalitas berasal dari kata profesi (profession) yang dapat diartikan sebagai jenis pekerjaan yang khas atau pekerjaan yang memerlukan pengetahuan. Profesi dapat juga diartikan sebagai beberapa keahlian atau ilmu pengetahuan yang digunakan dalam aplikasi untuk berhubungan dengan orang lain, instansi atau sebuah lembaga. Dalam kamus besar bahasa Indonesia profesi adalah bidang pekerjaan yang dilandasi keahlian tertentu.

\footnotetext{
${ }^{32}$ Dosen Tetap Program Studi Pendidikan Agama Islam STAI Auliaurrasyidin Tembilahan Kabupaten Indragiri Hilir Provinsi Riau
} 
Sedangkan arti dari profesional adalah seseorang yang memiliki seperangkat pengetahuan atau keahlian yang khas dari profesinya. ${ }^{33}$

Guru juga juga memiliki tugas profesionalitas, maka sebagai guru yang profesional akan mengetahui, memahami, dan menghayati bahwa sebuah profesi memiliki tugas, peran, dan tanggung jawab. Dalam pelaksanaan tugasnya, guru dituntut untuk memiliki kemampuan atau keterampilan yang beraneka ragam serta didasari bahwa kemampuan dan keterampilan sebagai kebutuhan dari sebuah profesi guru.

Profesionalisme merupakan suatu istilah baku dalam mempersiapkan sumber daya manusia abad 21 yang penuh persaingan. Ada yang menekankan profesionalisme kepada penguasaan ilmu pengetahuan beserta kiat-kiat dalam penerapannya. David H. Maister yang dikutip H.A.R. Tilaar (2002) menekankan profesionalisme bukan hanya sekedar pengetahuan teknologi dan manajemen tetapi profesionalisme lebih menekankan suatu sikap. Muhibbin Syah (2000), profesionalisme adalah sebuah kualitas dan tindak tanduk khusus yang merupakan ciri seorang yang profesional. $^{34}$

Undang-undang No. 14 Tahun 2005 tentang Guru dan Dosen, diberi rumusan, yaitu: professional adalah pekerjaan atau kegiatan yangdilakukan seseorang dan menjadi sumber penghasilan kehidupannya yang memerlukan keahlian, kemahiran, atau kecakapan yang memenuhi standar mutu atau norma tertentu, serta memerlukan pendidikan profesi. Selanjutnya guru yang profesional melakukan pekerjaan khusus yang dilaksanakan berdasarkan tujuh hal, yaitu (1) memiliki bakat, minat, panggilan jiwa, dan idealisme, (2) memiliki komitmen untuk meningkatkan

\footnotetext{
${ }^{33}$ M. Rasyid Ridla, Profesionalitas Guru Pendidikan Agama Islam dalam Proses Pembelajaran, Tadris. Volume 3. Nomor 1. 2008, h. 32.

${ }^{34}$ Kartilawati dan Mawaddatan Warohmah, Profesionalisme Guru Pendidikan Agama Islam di Era Teknologi Informasi dan Komunikasi, TA’DIB, Vol. XIX, No. 01, Edisi Juni 2014, h. 144-145.
} 
mutu pendidikan, keimanan, ketaqwaan, dan akhlak mulia, (3) memiliki kualifikasi akademik, profesi, dan latar belakang pendidikan sesuai dengan bidang tugas, (4) memiliki kompetensi yang diperlukan sesuai dengan bidang tugas, (5) memiliki tanggung jawab atas pelaksanaan tugas keprofesionalan, (6) memperoleh penghasilan yang ditentukan sesuai dengan prestasi kerja sehingga guru menjadi bangga akan profesi yang digelutinya, (7) dapat memanfaatkan teknologi informasi, (8) mampu berkomunikasi secara luas, dan (9) memiliki kesempatan untuk mengembangkan keprofesionalan secara berkelanjutan dengan belajar sepanjang hayat (long life learning) ${ }^{35}$ (UU Guru dan Dosen, 2011: 152). Yang menjadi penekanan dari kesembilan hal tersebut yaitu dapat memanfaatkan teknologi informasi dalam menunjang keprofesionalan guru.

Guru yang profesional bukan hanya sekedar alat untuk tranmisi kebudayaan tetapi mentransformasikan kebudayaan itu ke arah yang dinamis yang menuntut ilmu pengetahuan, produktivitas yang tinggi, dan kualitas yang dapat bersaing serta merupakan dinamisator yang mengantar potensi-potensi peserta didik ke arah kreativitas Ini semua disebabkan karena guru profesional berfungsi untuk mengajar, melatih, dan melaksanakan penelitian masalah-masalah pendidikan serta menjadi fasilitator untuk membantu peserta didik mentransformasikan potensi yang dimiliki peserta didik menjadik kemampuan serta keterampilan yang berkembang dan bermanfaat bagi manusia

Profesionalisme adalah sebutan yang mengacu pada sikap mental dalam bentuk komitmen dari para anggota suatu profesi untuk senantiasa mewujudkan dan meningkatkan kualitas profesionalnya. Profesionalisme

\footnotetext{
${ }^{35}$ Undang-undang RI tentang Guru dan Dosen No. 14 Tahun 2005. 2011. Sinar Grafika.
} 
pada intinya adalah kompetensi untuk melaksanakan tugas dan fungsinya secara baik dan benar. ${ }^{36}$

Paparan di atas memberikan keterangan, bahwa profesionalisme guru merupakan kemampuan dan kesanggupan guru dalam melaksanakan tugas dan fungsinya sebagai guru, serta memiliki komitmen untuk senantiasa meningkatkan kualitas profesinya. Hal ini dapat diukur dari kompetensi yang dimiliki guru, yaitu kompetensi paedagogik, kompetensi profesional, kompetensi kepribadian, kompetensi sosial.

Berbicara tentang profesionaliisme guru tentunya berhubungan dengan kompetensi yang dimiliki oleh guru sebagi tenaga pendidik. Yang harus memiliki kemampuan pedagogic, emosional, serta kemampuan sosial guru juga diharapkan mampu menjadi tenaga pendidik yang professional. Seperti yang teramanat pada UU No 14 Tahun 2005 tentang guru dan dosen yang berbunyi: "guru merupakan bagian dari sebuah profesi dan dituntut untuk dapat professional". Kompeten berada di dalam diri seseorang berupa kemampuan atau kecakapan untuk melakukan sesuatu,yang berkaitan dengan pola-pola perilaku.

\section{Kompetensi Profesionalisme Guru PAI}

Sosok utuh seorang lulusan program pendidikan profesi guru termasuk dalam hal ini guru Pendidikan Agama Islam (PAI) secara generik tertuang dalam Standar Kompetensi Guru (Permen no. 16 tahun 2007). Kompetensi guru tersebut semula disusun secara utuh, namun pada akhir proses peresmiannya menjadi peraturan menteri, diklasifikasikan ke dalam 4 kategori kompetensi dengan judul seperti tertera pada Peraturan Pemerintah

${ }^{36}$ Retoliah, Kinerja Pengawas dalam Meningkatkan Profesionalisme Guru PAI di Kota Palu, ISTIQRA, Jurnal Penelitian Ilmiah, Vol. 2, No. 2 Juni-Desember 2014 ISTIQRA, Jurnal Penelitian Ilmiah, ISSN: 2338-025X Vol. 2, Institut Agama Islam Negeri Palu, h. 372. 
Nomor 19 tahun 2005 tentang Standar Nasional Pendidikan. Kompetensi inti guru Pendidikan Agama Islam (PAI) dijabarkan sebagai berikut:

Pertama, kompetensi pedagogik. Kompetensi ini meliputi: a) penguasaan terhadap berbagai karakteristik peserta didik dari aspek fisik, moral, sosial, kultural, emosional, dan intelektual, b) penguasaan terhadap berbagai teori belajar dan prinsip-prinsip pembelajaran yang mendidik, c) menguasai kurikulum yang terkait dengan bidang pengembangan yang diampu, d) memiliki keterampilan dalam melakukan kegiatan pengembangan yang mendidik, e) dapat memanfaatkan teknologi informasi dan komunikasi untuk kepentingan penyelenggaraan kegiatan pengembangan yang mendidik, f) memfasilitasi pengembangan potensi peserta didik untuk mengaktualisasikan berbagai potensi yang dimiliki, g) mampu berkomunikasi secara efektif, empatik, dan santun dengan peserta didik, h) memiliki keterampilan dalam melakukan penilaian dan evaluasi proses dan hasil belajar, i) mampu memanfaatkan hasil penilaian dan evaluasi untuk kepentingan pembelajaran. dan j) selalu melakukan tindakan reflektif untuk peningkatan kualitas pembelajaran. Kedua, kompetensi kepribadian. Kompetensi ini meliputi; a) bertindak sesuai dengan norma agama, hukum, sosial, dan kebudayaan nasional Indonsia, b) menampilkan diri sebagai pribadi yang jujur, berakhlak mulia, dan teladan bagi peserta didik dan masyarakat. menampilkan diri sebagai pribadi yang mantap, stabil, dewasa, arif, dan berwibawa, menunjukkan etos kerja, tanggungjawab yang tinggi, rasa bangga menjadi guru, dan rasa percaya diri. menjunjung tinggi kode etik profesi guru. Ketiga, kompetensi sosial. Kompetensi ini meliputi: a) bersikap inklusif, bertindak objektif, serta tidak diskriminatif karena pertimbangan jenis kelamin, agama, ras, kondisi fisik, latar belakang keluarga, dan status sosial ekonomi. b) berkomunikasi secara efektif, empatik, dan santun dengan sesama pendidik, tenaga kependidikan, 
orang tua, dan masyarakat. c) beradaptasi di tempat bertugas di seluruh wilayah Republik Indonesia yang memiliki keragaman sosial budaya. d) berkomunikasi dengan komunitas profesi sendiri dan profesi lain secara lisan dan tulisan atau bentuk lain. Kempat, kompetensi professional. Kompetensi ini meliputi; a) menguasai materi, struktur, konsep, dan pola pikir keilmuan yang mendukung mata pelajaran yang diampu. b) menguasai standar kompetensi dan kompetensi dasar mata pelajaran/bidang pengembangan yang diampu. c) mengembangkan materi pembelajaran yang diampu secara kreatif. d) mengembangkan keprofesionalan secara berkelanjutan dengan melakukan tindakan reflektif. e) memanfaatkan teknologi informasi dan komunikasi untuk berkomunikasi dan mengembangkan diri. ${ }^{37}$

Standar kompetensi tersebut catatan berikut harus diperhatikan: Sebagai guru Pendidikan Agama Islam (PAI) profesional, penguasaan bidang studi tidak bersifat terisolasi. Dalam melaksanakan tugasnya penguasaan bidang studi terintegrasi dengan kemampuan memahami peserta didik, merancang pembelajaran, melaksanakan proses pembelajaran yang mendidik, dan mengevaluasi proses dan hasil pembelajaran. Sebagai seorang profesional, guru harus mengenal siapa dirinya, kekuatan, kelemahan, kewajiban dan arah pengembangan dirinya. Dunia yang selalu berubah menyebabkan tuntutan yang dinamis pula terhadap kecakapan guru. Karenanya guru harus pandai memilih strategi yang efektif untuk mengembangkan diri secara terus menerus.

Sardiman yang dikutip oleh Sitti Roskina Mas menyatakan bahwa krakteristik guru yang profesional terdiri dari: (1) capable, artinya guru memiliki tingkat pengetahuan, keahlian, untuk meningkatkan mutu

\footnotetext{
${ }^{37}$ Muhammad Nasir, Profesionalisme Guru Agama Islam (Sebuah Upaya Peningkatan Mutu Melalui LPTK), Dinamika Ilmu Vol. 13. No. 2, Desember 2013. h. 193194.
} 
pendidikan serta berkemampuan untuk mengubahnya menjadi sesuatu yang menguntungkan baik guru itu sendiri maupun anak didiknya, (2) inovator, artinya guru selalu berusaha untuk mencari terobosan-terobosan baru dalam menemukan solusi kesulitan siswa dalam proses belajar mengajar. Sehingga dapat dipetakannya kesulitan dalam pembelajarannya, dan (3) developer, artinya bahwa guru yang profesional senantiasa berusaha untuk mengembangkan dirinya sendiri dan juga mengembangkan berbagai model pembelajaran sehingga mampu untuk meningkatkan motivasi siswa. ${ }^{38}$

\section{Asas-asas Kompetensi Profesional Guru}

Asas-asas Kompetensi Profesional Guru Menurut Samana yang dikutip oleh Nur Hasanah, dari 11 kompetensi profesional guru tersebut dalam pelaksanaannya diperlukan prinsip-prinsip/ asas-asas pembelajaran yang tepat yang meliputi :

a. Asas siswa aktif

Pada dasarnya anak adalah makhluk yang aktif. Hal ini dapat dipertanggungjawabkan dari misi filosofis, psikologis biologis, dan sosiologis yang bertalian dengan kehidupan anak. Pembelajaran merupakan kegiatan kemanusiaan yang fundamental, maka wajarlah guru dan siswa dituntut aktif dalam meaksanakan perannya. Karena belajar pada dasarnya bagaimana membelajarkan siswa.

b. Asas motivasi dalam dalam belajar

Motivasi merupakan dorongan yang menjadikan seseorang melakukan kegiatan belajar. Motivasi ini dapat bersifat intrinsik dan ekstrinsik. Guru dituntut untuk cakap membangun motivasi belajar siswa.

${ }^{38}$ Sitti Roskina Mas, Profesionalisme Guru dalam Peningkatan Kualitas pembelajaran, INOVASI, Volume 5, Nomor 2, Juni 2008 ISSN 1693-9034, Fakultas Sastra dan Budaya Universitas Negeri Gorontalo. h, 3 
c. Asas pusat minat

Dalam upaya membangun minat siswa guru hendaknya berusaha keras untuk menjelaskan makna, arah, kegunaan, keindahan, keunikan, dan nilai positif dari bahan yang wajib dipelajari oleh siswa. Guru dituntut menguasai bahan ajar secara mendalam, berstruktur, sehingga siswa belajar sesuatu yang bermakna dalam interaksinya dengan guru.

d. Asas apersepsi, korelasi dan integrasi

Penerapan asas apersepsi dalam pembelajaran adalah penyandaran serta penggunaan pengetahuan yang telah dimiliki oleh siswa sebagai titik tolak pembahasan bahan ajar yang baru. Sedangkan Penerapan asas korelasi dalam pembelajaran adalah menghubungkan antar data , konsep, prinsip, dan generalisasi yang menjadi pembahasan agar keseluruhan hasil belajar jelas, mendalam, dan berstruktur. Dan penerapan asas integrasi dalam pembelajaran adalah mengutuhkan perolehan belajar siswa yang ditandai dengan :

e. Asas individualisasi

Dalam asas ini pembelajaran hendaknya disesuaikan dengan kondisi, potensi, sifat, minat, taraf perkembangan, dan kebutuhan siswa. Guru hendaknya dapat mengatur kelas secara fleksibel. Penerapa asas ini yang berhasil ditandai dengan optimalisasi perolehan belajar siswa selaras dengan potensinya, perkembangan multi talent (seluruh aspek) serta bakatnya berkembang secara wajar dan berimbang), integrasi diri, dan para siswa mengalami keluasan hidup.

f. Asas peraga

Asas peragaan merupakan konkritisasi pesan pembelajarn agar mudah dikuasai oleh siswa. Oleh karena itu guru menguasai media dan teknologi pembelajaran. 


\section{g. Asas kooperasi}

Asas kooperasi dalam pembelajaran adalah pengaturan kerja kelompok dan pembinaan kompetensi yang sehat. Kooperasi dan kompetensi jangan dipandang sebagai dua kutub yang saling tarik menarik, tetapi perlu diusahakan oleh guru agar kompetensi justru jadi penggerak dinamika kelompok dan dasar pelayanan bimbingan belajar perorangan.

h. Asas pengajaran multi sumber

Asas ini guru mampu menjabarkan serta mengorganisasikan bahan ajar secara sistematis dengan mendayagunakan aneka sumber belajar yang semakin banyak dalam masyarakat. Dan mengingat taraf kematangan berpikir siswa ,guru mampu menjabarkan serta mengorganisasikan bahan ajar dengan kajian yang bersifat komparatif, kontekstual, selain disiplin keilmuan, penuh alternati, dan sistematisintegratif.

i. Asas kesinambungan belajar

Penerapan asan berkesinambungan ini tampak dalam: Pendampingan proses belajar siswa secara efektif-efisien. (mencapai hasil belajar yang terstandar). Tersedianya kondisi (fasilitas) dan situasi belajar yang kondusif, adanya tata urutan bahan ajar atau pengalaman belajar yang terkait secara sistematis dan logis serta sesuai dengan kebutuhan siswa.

j. Asas penilaian

Penilaian dalam pembelajaran dapat digunakan untuk mengetahui mutu kerja guru dan mutu belajar siswa. Data penilaian dapat digunakan sebagai umpan balik bagi guru dan siswa untuk berbenah diri serta mencari perkembangan lebih lanjut. ${ }^{39}$

${ }^{39}$ Nur Hasanah, Dampak Kompetensi Profesional Guru dalam Meningkatkan Mutu Pendidikan Madrasah Ibtidaiyah di Kota Salatiga, INFERENSI, Jurnal Penelitian Sosial Keagamaan, Vol. 9, No. 2, Desember 2015, Institut Agama Islam Negeri Salatiga. h. 448-451. 
Adanya penilaian tentang belum profesionalnya guru diakui dan ditanggapi secara bijak baik oleh guru itu sendiri, institusi penghasil guru (LPTK) pemerintah maupun pengguna. Penilaian atau kritik itu hendaknya dapat dijadikan sebagai bahan refleksi serta dijadikan tantangan untuk memecut semangat dalam mewujudkan profesionalisme guru.

Profesionalisme guru merupakan suatu keharusan sebab tanpa profesionalisasi perwujudan guru profesional sulit dicapai. Guru yang profesional adalah guru yang bekerja secara otonom (bebas tetapi sesuai keahlian dan mandiri). Untuk mengabdikan diri pada pengguna jasa (negara dan masyarakat) dengan disertai tanggung jawab atas kemampuan profesionalismenya sebab penyandang suatu profesi. Untuk itu dibutuhkan profesionalisasi, yaitu proses peningkatan kualifikasi atau kompetensi bagi penyandang suatu profesi untuk mencapai kriteria standar ideal yang ditetapkan profesinya. Sudarwan Danim menjelaskan 3 pendekatan profesionalisasi profesi meliputi:

a. Pendekatan karakteristik (the treat approach) yang memfokuskan pada profesi memiliki seperangkat elemen antara lain: kemampuan intelektual diperoleh dari pendidikan tinggi memiliki pengetahuan spesialisasi, memiliki pengetahuan dan teknis yang dapat dikomunikasikan, kemandirian, kode etik dan sistem upah serta budaya professional

b. Pendekatan institusional (the institusional approach). Memandang profesi dari sudut pandang proses institusional atau perkembangan asosiasional.

c. Pendekatan legalistik (the legalistik approach) menekankan adanya pengakuan atas suatu profesi oleh negara atau pemerintah. Pengakuan 
terhadap profesi dapat ditempuh melalui tahapan registrasi, sertifikasi dan lisensi. ${ }^{40}$

\section{Aplikasi Profesionalisme Guru PAI}

Dalam aplikasinya, profesionalisme pada jabatan guru (agama) ditunjukkan dari sikap-sikap profesional dalam pelaksanaan tugas. Guru agama yang profesional sebagai sosok yang kaya akan ilmu pengetahuan, memiliki kemampuan dalam bidang keguruan, memberikan pertolongan, bimbingan dan tauladan kepada siswa, sehingga berhasil mencapai tujuan pendidikan Islam. Ahmad Tafsir, yang dikutip oleh Jaka Siswanta, menegaskan bahwa jabatan profesional kependidikan Islam, yakni:

a. Profesi memiliki keahlian yang bersifat khusus.

b. Profesi diambil sebagai pemenuhan panggilan hidup atau panggilan atas pengabdiaannya kepada masyarakat.

c. Profesi memiliki teori-teori yang baku secara universal, yang berkaitan dengan keahlian sebagai tersebut di atas.

d. Profesi adalah untuk masyarakat sebagai alat pengabdian diri kepada masyarakat bukan untuk kepentingan diri pribadi, mengejar jabatan atau kedudukan.

e. Profesi dilengkapi dengan kecakapan dan kompetensi aplikatif.

f. Pemegang profesi memiliki otonomi dalam melakukan tugas profesinya.

g. Profesi memilik kode etik.

h. Profesi mempunyai klien yang jelas (siswa sebagai pemakai jasa profesi guru).

i. Profesi memerlukan organisasi profesi.

${ }^{40}$ Pujiyana, Proceeding Seminar Nasional "Profesionalisme Guru Dalam Perspektif Global” Tahun 2012, ISBN: 978-602-18235-0-7.FKIP Universitas Veteran Bangun Nusantara Sukoharjo. h. 131. 
j. Profesi mengenali hubungan antara profesinya dengan bidang-bidang lain. $^{41}$

\section{Kompetensi Profesional Guru Agama Islam di Madrasah}

Setiap ilmuan tentu memiliki tingkat wawasan yang berbeda antara seorang ilmuan dengan ilmuan lainnya. Meskipun berbeda tetapi secara aturan yang lazim berlaku, wawawan keilmuan seseorang itu terbagi ke dalam dua hal yaitu wawasan keilmuan yang terkait dengan lingkup keilmuan itu sendiri dan wawasan keilmuan yang terkait di luar dari lingkup keilmuan itu. Wawasan keilmuan yang terkait dengan lingkup keilmuan itu sendiri umpamanya seorang ilmuan fikih memahami ilmu ushul fikih, ilmu mashailul fikih, ilmu perbandingan mazhab, dan lain sebagainya. Wawasan kelimuan yang terkait diluar lingkup keilmuan itu umpamanya seorang ilmuan fikih memahami ulumul Qur”an, ulumul hadits, ilmu kalam, ilmu tasauf dan lain sebagainya. Sesuai dengan penjelasan permendikbud No 16 Tahun 2007 tentang kompetensi profesional guru, maka seorang guru agama Islam baik yang mengajar di madrasah maupun wajib memiliki wawasan keilmuan yang terkait dengan mata pelajaran pendidikan agama islam yaitu mata pelajaran Al-Quran-Hadits, Fikih, Akidah-Akhlak, dan Sejarah Islam. Tidak bisa seorang guru pendidikan agama Islam khususnya di madrasah mengatakan bahwa dia hanya guru mata pelajaran Fikih dan tidak perlu mengetahui mata pelajaran Al-Quran-Hadits sebab meskipun pada madrasah ke empat mata pelajaran itu berdiri sendiri namun secara konten di dalam proses pembelajaran ke empat mata pelajaran itu merupakan satu kesatuan yang tak dapat dipisahkan satu dengan yang lainnya. Sama halnya dengan guru agama Islam yang mengajar di madrasah, maka guru agama Islam yang

\footnotetext{
${ }^{41}$ Jaka Siswanta, Kompetensi Profesionalisme Guru Pendidikan Agama Islam (PAI) di Sekolah Umum Tingkat SMA/SMK Kabupaten Magelang,INFERENSI, Jurnal Penelitian Sosial Keagamaan, Vol. 6, No. 2, Desember 2012: 349-370. Sekolah Tinggi Agama Islam Negeri (STAIN) Salatiga, h. 358-359.
} 
ada di sekolah tentu lebih sangat wajib memiliki wawasan keilmuan yang terkait dengan mata pelajaran pendidikan agama Islam karena pada sekolah, mata pelajaran ini merupakan satu kesatuan yang utuh. ${ }^{42}$

\section{Kesimpulan}

Sesuai dengan penjelasan permendikbud No 16 Tahun 2007 tentang kompetensi profesional guru, maka guru agama Islam baik yang mengajar di madrasah maupun ditempat lain wajib memiliki wawasan keilmuan yang terkait dengan mata pelajaran pendidikan agama Islam yaitu mata pelajaran Al-Quran-Hadits, Fikih, Akidah-Akhlak, dan Sejarah Islam. Tidak patut, seorang guru pendidikan agama Islam khususnya di madrasah mengatakan bahwa ianya hanya guru mata pelajaran Fikih dan tidak perlu mengetahui mata pelajaran Al-Quran-Hadits, sebab meskipun pada madrasah ke empat mata pelajaran itu merupakan satu kesatuan sendiri namun secara konten di dalam proses pembelajaran ke empat mata pelajaran itu merupakan kesatuan yang tak dapat dipisahkan antara satu dengan lainnya.

\section{Referensi}

Siswanta Jaka, Kompetensi Profesionalisme Guru Pendidikan Agama Islam (PAI) di Sekolah Umum Tingkat SMA/SMK Kabupaten Magelang, INFERENSI, Jurnal Penelitian Sosial Keagamaan, Vol. 6, No. 2, Desember 2012: 349-370.

Kartilawati dan Mawaddatan Warohmah, Profesionalisme Guru Pendidikan Agama Islam di Era Teknologi Informasi dan Komunikasi, TA’DIB, Vol. XIX, No. 01, Edisi Juni 2014.

M. Rasyid Ridla, Profesionalitas Guru Pendidikan Agama Islam dalam Proses Pembelajaran, Tadris. Volume 3. Nomor 1. 2008.

\footnotetext{
${ }^{42}$ Marinasari Fithry Hasibuan, Kompetensi Profesional Guru Pendidikan Agama Islam pada Sekolah dan Madrasah, (Widyaiswara Balai Diklat Keagamaan Medan, http://sumut.kemenag.go.id/06/04/2015), h. 3
} 
Marinasari Fithry Hasibuan, Kompetensi Profesional Guru Pendidikan Agama Islam pada Sekolah dan Madrasah, Widyaiswara Balai Diklat Keagamaan Medan, http://sumut.kemenag.go.id/06/04/2015.

Muhammad Nasir, Profesionalisme Guru Agama Islam (Sebuah Upaya Peningkatan Mutu Melalui LPTK), Dinamika Ilmu Vol. 13. No. 2, Desember 2013.

Nur Hasanah, Dampak Kompetensi Profesional Guru dalam Meningkatkan Mutu Pendidikan Madrasah Ibtidaiyah di Kota Salatiga, INFERENSI, Jurnal Penelitian Sosial Keagamaan, Vol. 9, No. 2, Desember 2015, Institut Agama Islam Negeri Salatiga.

Pujiyana,Proceeding Seminar Nasional "Profesionalisme Guru Dalam Perspektif Global" Tahun 2012, ISBN: 978-602-18235-0-7.FKIP Universitas Veteran Bangun Nusantara Sukoharjo.

Retoliah, Kinerja Pengawas dalam Meningkatkan Profesionalisme Guru PAI di Kota Palu, ISTIQRA, Jurnal Penelitian Ilmiah, Vol. 2, No. 2 Juni-Desember 2014 ISTIQRA, Jurnal Penelitian Ilmiah, ISSN: 2338-025X Vol. 2, Institut Agama Islam Negeri Palu.

Undang-undang RI tentang Guru dan Dosen No. 14 Tahun 2005. 2011. Sinar Grafika. 